Subscriber access provided by Caltech Library

\title{
Letter
}

\section{Enzymatic Lactone-Carbene C\#H Insertion to Build Contiguous Chiral Centers}

\author{
Andrew Z. Zhou, Kai Chen, and Frances H. Arnold
}

ACS Catal., Just Accepted Manuscript • DOI: 10.1021/acscatal.0c01349 • Publication Date (Web): 21 Apr 2020

Downloaded from pubs.acs.org on April 21, 2020

\section{Just Accepted}

"Just Accepted" manuscripts have been peer-reviewed and accepted for publication. They are posted online prior to technical editing, formatting for publication and author proofing. The American Chemical Society provides "Just Accepted" as a service to the research community to expedite the dissemination of scientific material as soon as possible after acceptance. "Just Accepted" manuscripts appear in full in PDF format accompanied by an HTML abstract. "Just Accepted" manuscripts have been fully peer reviewed, but should not be considered the official version of record. They are citable by the Digital Object Identifier (DOI®). "Just Accepted" is an optional service offered to authors. Therefore, the "Just Accepted" Web site may not include all articles that will be published in the journal. After a manuscript is technically edited and formatted, it will be removed from the "Just Accepted" Web site and published as an ASAP article. Note that technical editing may introduce minor changes to the manuscript text and/or graphics which could affect content, and all legal disclaimers and ethical guidelines that apply to the journal pertain. ACS cannot be held responsible for errors or consequences arising from the use of information contained in these "Just Accepted" manuscripts. 
Direct functionalization of carbon-hydrogen bonds represents a powerful and efficient strategy for installing new chemical moieties in organic compounds. ${ }^{1}$ In particular, enantioselective $\mathrm{C}\left(s p^{3}\right)-\mathrm{H}$ alkylation via carbene insertion into $\mathrm{C}-\mathrm{H}$ bonds provides a platform for $\mathrm{C}\left(s p^{3}\right)-\mathrm{C}\left(s p^{3}\right)$ bond formation to build diverse molecular skeletons and for late-stage modification of complex molecules. ${ }^{2}$ Transition-metal catalysts based on rhodium, ${ }^{3}$ iridium, ${ }^{4}$ cobalt, ${ }^{5}$ copper, ${ }^{6}$ and other metals ${ }^{7}$ have been shown to catalyze carbene insertion into $\mathrm{C}-\mathrm{H}$ bonds. In most reported methods, carbenes bearing one electron-donating aryl/alkenyl group and one electron-withdrawing group ('donor-acceptor carbenes') have been demonstrated to be superior for intermolecular $\mathrm{C}-\mathrm{H}$ insertions, with control over reactivity and selectivity in these catalytic systems. ${ }^{8}$ Dirhodium catalysts, for example, have achieved site-selective functionalization of various types of $\mathrm{C}-\mathrm{H}$ bonds through the manipulation of ligand scaffolds. ${ }^{9}$ Other carbenes, however, such as acceptor-only carbenes, are less explored for $\mathrm{C}-\mathrm{H}$ insertion reactions; $4 \mathrm{~b}, 6 \mathrm{a}, 7 \mathrm{c}$ acceptor-only carbenes with an additional alkyl substituent at the $\alpha$-position are even more challenging to use in these systems due to competitive $\beta$ hydride migration upon the formation of the metallo-carbene species. ${ }^{10}$

Recently, we reported that a cytochrome P450, which uses an iron-heme cofactor for its native oxygenase activity, can be engineered to transfer carbene moieties to $\mathrm{C}-\mathrm{H}$ bonds using diazo compounds bearing a single electron-withdrawing substituent (Figure 1). ${ }^{11,12}$ Engineered P450 enzymes substituted with serine as the heme-ligating residue ('P411s') $)^{13}$ were established as an efficient platform for stereoselective $\mathrm{C}-\mathrm{C}$ bond assembly with a chiral center formed at the $\beta$ position. We thus anticipated that the P411 enzymes could be evolved further to adopt branched carbenes for $\mathrm{C}-\mathrm{H}$ insertion, which would enable them to build a chiral center at $\alpha$-position or even contiguous chiral centers at both the $\alpha$ and $\beta$-positions.
Rather than using the well-studied donor-acceptor carbenes, we focused on lactone-based carbenes, which are difficult to use with rhodium catalysts due to challenges with $\beta$-H elimination and stereocontrol. ${ }^{14}$ Despite limited examples of $\mathrm{C}-\mathrm{H}$ insertion with cyclic carbenes, ${ }^{15}$ we previously revealed that lactonebased carbenes can be transferred to different functionalities with high efficiency and stereoselectivity using engineered hemeprotein catalysts. ${ }^{16,17}$ Those studies demonstrated the enzymes' ability to stabilize the lactone-carbene intermediates, circumvent undesired $\beta-\mathrm{H}$ migration, and facilitate carbene transfer with exquisite stereocontrol, thus laying the foundation for the current study.

We initiated this investigation of $\mathrm{C}-\mathrm{H}$ functionalization with $\alpha$ diazo- $\gamma$-lactone (LAD) and 4,N,N-trimethylaniline (1a) as substrates (Figure 2). ${ }^{18}$ The expected carbene-transfer reaction leads to the formation of a $\beta$-amino lactone product, $2 \mathbf{a}$, through carbene insertion into an $\alpha$-amino $\mathrm{C}-\mathrm{H}$ bond with a chiral center generated at the $\alpha$-position. Such $\beta$-amino lactone products are analogs of sesquiterpene-lactone amino derivatives, which possess desirable pharmaceutical properties. ${ }^{19}$ Screening various hemeproteins, including P450 variants, P411s, and cytochromes $c$ in the form of whole Escherichia coli (E. coli) cell catalysts identified a P411 variant, P411-C10, capable of the desired $\mathrm{C}-\mathrm{H}$ insertion transformation (Figure 1). P411C10, a promiscuous enzyme for different carbene-transfer chemistries including internal cyclopropene formation, ${ }^{20}$ catalyzed the $\mathrm{C}-\mathrm{H}$ insertion reaction using a cyclic carbene with modest efficiency (105 TTN) and stereoselectivity (47\% ee). 


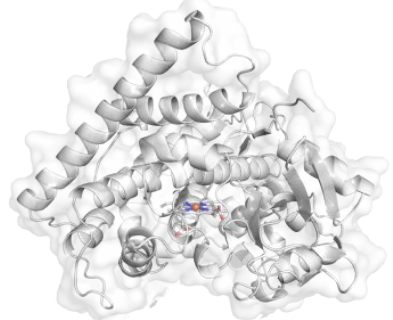

cytochrome P411 heme protein carbene transferase

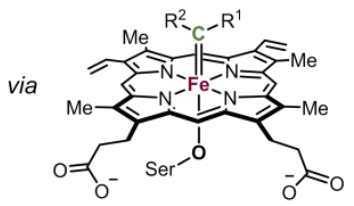

iron-carbene intermediate
P411-catalyzed carbene insertion into $\mathrm{C}-\mathrm{H}$ bonds

Previous work:

$$
\text { This work: }
$$

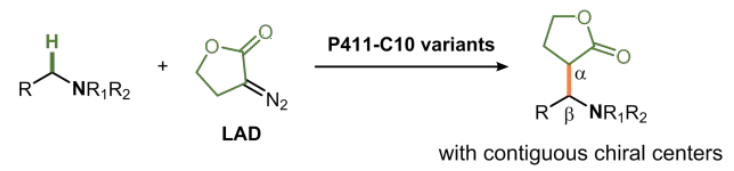

Figure 1. Enzymatic carbene insertion into $\mathrm{C}-\mathrm{H}$ bonds.

To enhance enzyme activity and selectivity by directed evolution, we targeted active-site residues for site-saturation mutagenesis and screening (Figure 2). Loop residues in the enzyme's active site were tested first, and beneficial mutations T327V and Q437L together increased total turnovers 9-fold. However, enantioselectivity decreased to $40 \%$ ee after three rounds of evolution. As substrate 1a is symmetric, we hypothesized it might bind with different orientations relative to the carbene intermediate, which would lead to the diminished stereoselectivity. To address this, we next targeted amino acids previously shown to dramatically affect stereoselectivity in either native or non-native functions of this $\mathrm{P} 450$, such as sites $87,264,268$, and $328 .^{13 b-d, 21}$ Screening a site-saturation library at site 87 for increased enantioselectivity resulted in discovery of a proline mutation giving $56 \%$ ee, albeit with decreased TTN. Residue 264 is the closest residue to the iron center, which may also influence binding of substrate or the orientation of the carbene intermediate. The A264S mutation improved both activity and enantioselectivity. Revisiting site 327 identified another proline mutation, which boosted the ee to $75 \%$. The three mutations A87P, A264S, and V327P may have improved enantioselectivity by providing a more restricted binding mode for substrate 1a in the enzyme.

Further rounds of evolution accumulated two more mutations, E264D and V328L, to give final variant $\mathbf{L 9}$ that produces 2a with $90 \%$ ee. Although the TTN of $\mathbf{L 9}$ dropped to approximately 600 under screening conditions, optimization of enzyme expression and reaction conditions improved TTN 1.5to 2.5-fold (Figure 3, entry 2a; and see Table S3 in SI). Another variant, L10, with a V328R mutation obtained from the 328X site-saturation library, showed the opposite stereo-preference ( $-68 \%$ ee) for this $\mathrm{C}-\mathrm{H}$ insertion reaction, suggesting that this biocatalytic platform may be tunable for enantio-divergent synthesis. $^{22}$

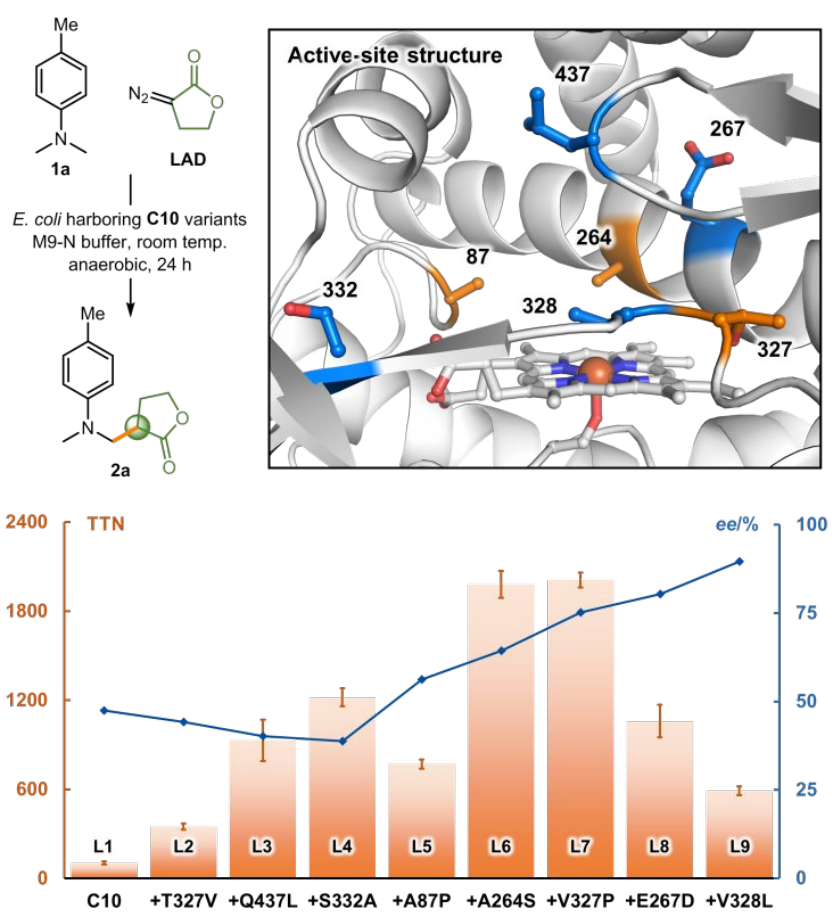

Figure 2. Directed evolution of P411-C10 for lactone-carbene insertion into $\boldsymbol{\alpha}$-amino $\mathbf{C}-\mathbf{H}$ bonds. Reactions were performed in quadruplicate under the following conditions: $10 \mathrm{mM} \mathrm{4,N,N-}$ trimethyl aniline (1a), $10 \mathrm{mM}$ LAD, E. coli harboring P411-C10 variants $\left(\mathrm{OD}_{600}=15\right.$ to 60$)$, D-glucose $(25 \mathrm{mM})$, M9-N buffer/EtOH (19:1), anaerobic, $24 \mathrm{~h}$. Product formation was quantified by high-performance liquid chromatography (HPLC), TTNs were determined based on protein concentration, and enantioselectivity was measured using chiral HPLC. The hemedomain structure of P411-E10 variant, an enzyme previously evolved for $\mathrm{C}-\mathrm{H}$ amination with high sequence identity to P411C10, (pdb: 5UCW) was used to guide site-saturation mutagenesis; mutation sites are highlighted. See Tables S1, S2 in SI for details.

As different variants in the enzyme lineage (L1 to L10) showed different levels of activity or selectivity for the $\mathrm{C}-\mathrm{H}$ insertion reaction, we selected representative variants ( $\mathbf{L 6}$ to $\mathbf{L 1 0})$ with which to evaluate the transformation of various $N, N$-dialkyl aniline derivatives, as shown in Figure 3. Substituents on the phenyl ring, including methyl, methoxyl or halide, are all compatible with the biocatalytic system, giving TTNs ranging from 410 to 2920. Variants L9 and L10 showed consistently opposite stereo-preference for diverse substrates (e.g., for $\mathbf{2 d}$ and $\mathbf{2 e}, 84 \%$ ee and $75 \%$ ee with $\mathbf{L 9},-55 \%$ and $-86.5 \%$ ee with L10), whereas activity had different trends in some cases (e.g., for 2d and 2e, 1410 TTN and 410 TTN with L9, 720 TTN and 1800 TTN with L10). Interestingly, with $N$-methyl, $N$-ethyl aniline (1g), $\mathbf{L 9}$ only synthesized the primary $\mathrm{C}-\mathrm{H}$ insertion product 2g with high efficiency (1710 TTN) and high enantioselectivity ( $95 \%$ ee); $\mathbf{L 1 0}$, in contrast, gave a mixture of the primary and secondary $\mathrm{C}-\mathrm{H}$ insertion products, $\mathbf{2 g}$ and $\mathbf{2 g}$ ', with a ratio of 71:29, where product $\mathbf{2 g}$ ' was found to be mainly a single diastereomer and enantiomer ( $>95: 5$ d.r. and $98 \%$ ee). Based on this result, we anticipated that this enzyme lineage may have the potential to functionalize secondary $\mathrm{C}-\mathrm{H}$ bonds to build contiguous chiral centers. 


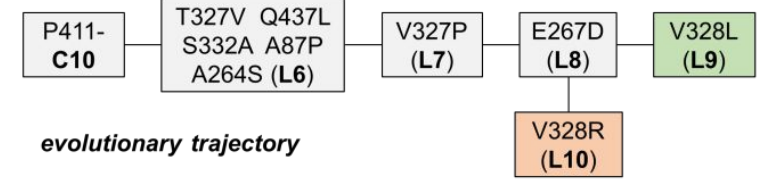

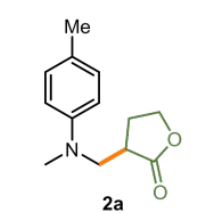

L7: 2920 TTN, $75 \%$ ee L9: 1550 TTN, $90.5 \%$ ee L10: 360 TTN, $-68 \%$ ee

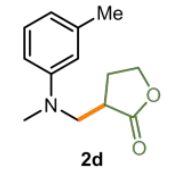
L9: 1410 TTN, $84 \%$ ee L10: 720 TTN, $-55 \%$ ee
L6: 1310 TTN, $-12 \%$ ee

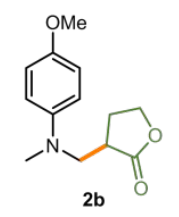

L6: 2040 TTN, $61 \%$ ee L7: 1830 TTN, $70 \%$ ee L9: 1160 TTN, $90 \%$ ee

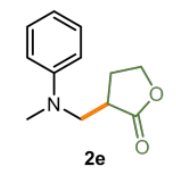

L6: 580 TTN, $18 \%$ ee L9: 410 TTN, $75 \%$ ee L10: 1800 TTN, $-86.5 \%$ ee

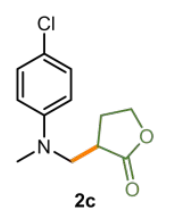

L7: 420 TTN, $76.5 \%$ ee

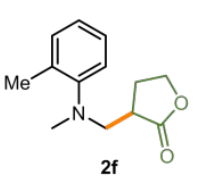

L9: 1480 TTN, $74.5 \%$ ee

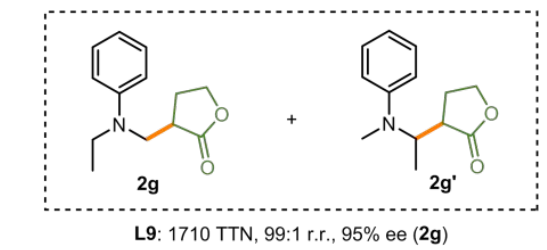

L10: 1120 TTN, $71: 29$ r.r., $-62 \%$ ee $(\mathbf{2 g}),>95: 5$ d.r., $97.5 \%$ ee $\left(\mathbf{2} \mathbf{g}^{\prime}\right)$

Figure 3. Scope of lactone-carbene insertion into $\alpha$-amino primary $\mathbf{C}-\mathbf{H}$ bonds. Reactions were performed in triplicate or quadruplicate under the following conditions: $12 \mathrm{mM}$ aniline derivatives, $12 \mathrm{mM}$ LAD, E. coli harboring P411-C10 variants $\left(\mathrm{OD}_{600}=30\right.$ or 60$)$, D-glucose $(25 \mathrm{mM}), \mathrm{M} 9-\mathrm{N}$ buffer/EtOH (19:1), anaerobic, $24 \mathrm{~h}$. Product formation was quantified by HPLC and TTNs were determined based on protein concentration. Enantioselectivity was measured using chiral HPLC and regioselectivity was determined by HPLC and NMR. See Tables S4-S7 in SI for details.

To explore the enzymes' ability to insert the lactone-carbene into secondary $\mathrm{C}-\mathrm{H}$ bonds, we selected dialkyl-aniline, pyrrolidine, azetidine, and other $N$-aryl amine derivatives as substrates. We first screened the entire enzyme lineage with more than 10 substrates in 96-well plates (See Tables S4, S5 in $\mathrm{SI}$ ). We were pleasantly surprised to see that many of the reactions formed the corresponding $\mathrm{C}-\mathrm{H}$ insertion products. We picked the most promising combinations of enzyme variants and substrates for validation and further confirmation of the products. As shown in Figure 4, the enzymes are particularly efficient toward carbene insertion into secondary $\mathrm{C}-\mathrm{H}$ bonds, giving up to 4000 TTN. The final two variants, L9 and L10, gave good to high diastereoselectivities and enantioselectivities. For instance, $\mathbf{L 9}$ and $\mathbf{L 1 0}$ formed the same diastereomer with diethyl aniline (1h), giving 94:6 d.r. and 99:1 d.r., respectively; however, the diastereomers were obtained with opposite enantioselectivity $(81 \%$ ee and $-94.5 \%$ ee, respectively). The same trend was observed with $N$-phenyl pyrrolidine (1i). With 2,3-dimethyl phenylpyrrolidine (1k), only moderate diastereoselectivity was achieved with the selected variants, but the diastereomers can be separated easily by chromatography, and high enantioselectivity was observed

for both diastereomers (up to $96 \%$ ee and $99 \%$ ee, respectively). Finally, $N$-phenyl azetidine (1m), which has a higher C-H bond dissociation energy on a strained ring, ${ }^{23}$ was also active for $\mathrm{C}-\mathrm{H}$ insertion, but only poor enantioselectivity was achieved ( $>95: 5$ d.r. and $13 \%$ ee for product $\mathbf{2 m}$ ), presumably reflecting its distinct structure from that of substrate 1a used for evolution.

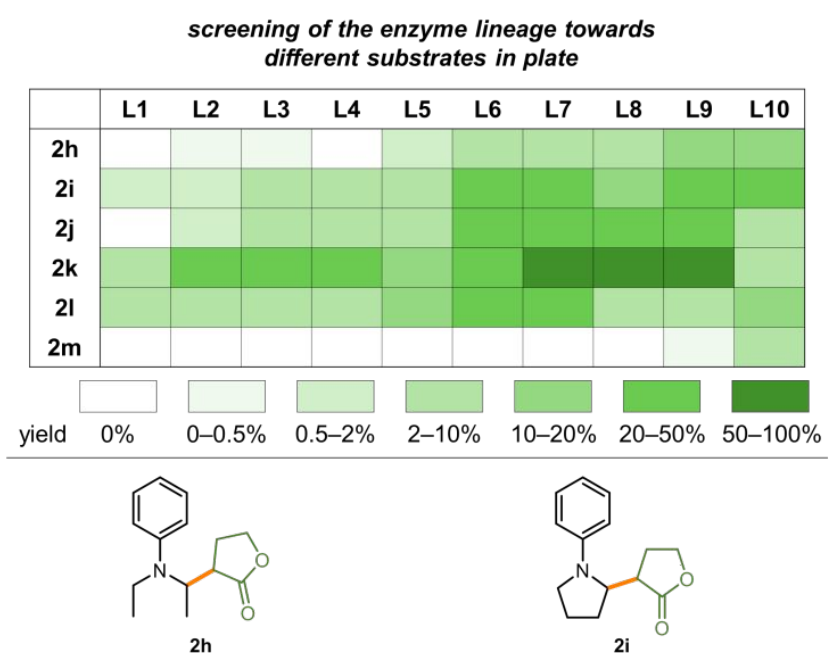

L6: 600 TTN, $78: 22$ d.r., $41 \%$ ee/ $-30 \%$ ee L9: 850 TTN, $94: 6$ d.r., $81 \%$ ee/ $-15 \%$ ee L10: 740 TTN, $99: 1$ d.r., $-94.5 \%$ ee/ $-19 \%$ ee

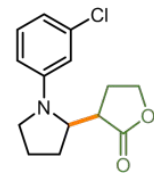

2j

L6: 960 TTN, $34: 66$ d.r., $95 \%$ ee/- $27 \%$ ee L8: 860 TTN, $41: 59$ d.r., $96 \%$ ee $/ 7 \%$ ee L9: 1460 TTN, $88: 12$ d.r., $91 \%$ ee/ $14 \%$ ee

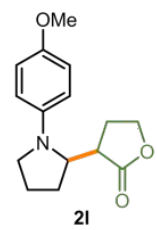

6. 960 TTN $52: 48$ dr. $93 \%$ ee $/ 26 \%$ ee L7: 1260 TTN, $58: 42$ d.r., $98 \%$ ee/- $52 \%$ ee L9: 210 TTN, $80: 20$ d.r., $98 \%$ ee $/ 78.5 \%$ ee
L6: 2550 TTN, $52: 48$ d.r., $94.5 \%$ ee/ $-24 \%$ ee L9: 1430 TTN, $88: 12$ d.r., $86.5 \%$ ee/ $-72.5 \%$ ee L10: 1490 TTN, $96: 4$ d.r., $-72 \%$ ee/- $30 \%$ ee

Figure 4. Scope of lactone-carbene insertion into $\alpha$-amino secondary $\mathbf{C}-\mathbf{H}$ bonds. Reactions were performed in triplicate or quadruplicate under the following conditions: $12 \mathrm{mM}$ aniline/pyrrolidine/azetidine derivatives, $12 \mathrm{mM}$ LAD, E. coli harboring P411-C10 variants $\left(\mathrm{OD}_{600}=30\right.$ or 60$)$, D-glucose $(25$ $\mathrm{mM}$, M9-N buffer/EtOH (19:1), anaerobic, 24 h. Product formation was quantified by HPLC and TTNs were determined based on protein concentration. Enantioselectivity was measured using chiral HPLC and regioselectivity was determined by HPLC and/or NMR. See Tables S4-S7 in SI for details.

It is worth revisiting the cases where $\mathbf{L 9}$ and $\mathbf{L 1 0}$ formed the same major diastereomer but the opposite enantiomer in carbene insertion into secondary $\mathrm{C}-\mathrm{H}$ bonds. This suggests that the single mutation going from $\mathbf{L 9}$ to $\mathbf{L 1 0}, \mathrm{L} 328 \mathrm{R}$, inverted two chiral centers simultaneously. As leucine and arginine possess very distinct features, we reasoned that the two residues might drive opposite orientations of the carbene intermediates with the hydrophobic side facing L328 and the hydrophilic side facing R328 (Figure 5). Then C-H insertion might take place with the 
substrate approaching from different sides to give the opposite enantiomers. The detailed mechanism of $\mathrm{C}-\mathrm{H}$ insertion, however, is still elusive--the reaction can undergo a radical pathway of hydrogen atom abstraction followed by radical rebound ${ }^{24}$ or a concerted insertion pathway, ${ }^{25,26}$ which may further affect the stereochemistry of the $\alpha$-chiral center. ${ }^{27}$ Mechanistic studies are ongoing to gain further insights into the $\mathrm{C}-\mathrm{H}$ insertion reactions.

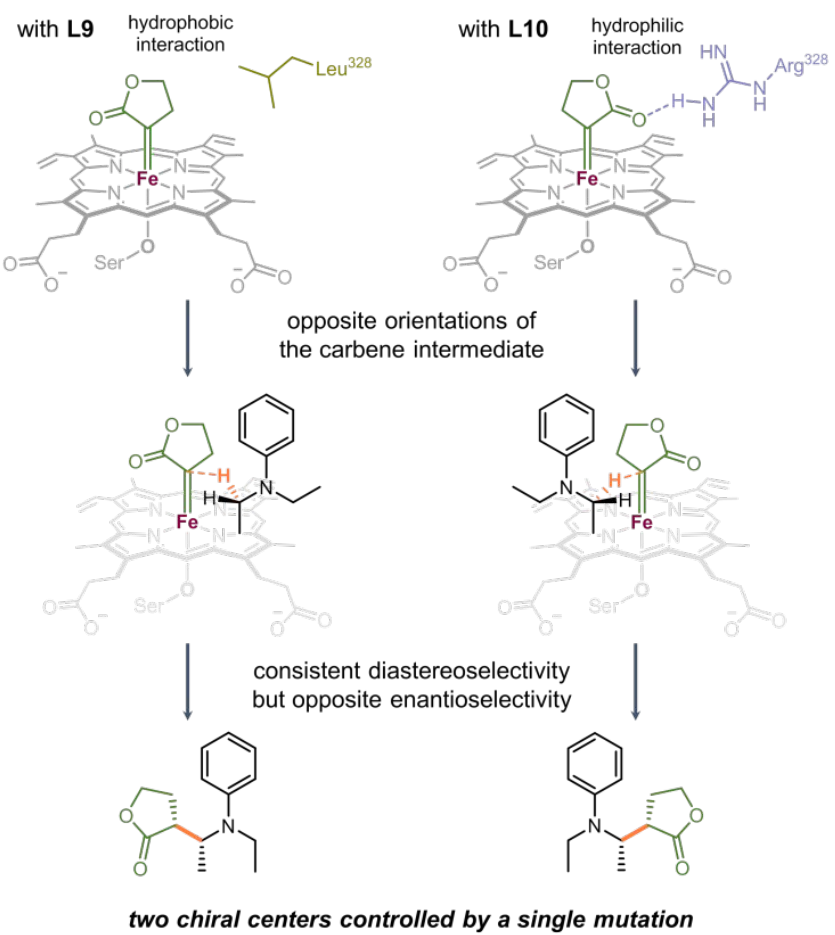

Figure 5. Possible explanation for stereocontrol in lactonecarbene insertion into secondary $\mathrm{C}-\mathrm{H}$ bonds.

In conclusion, we have developed an efficient biocatalytic platform to assemble $\mathrm{C}\left(s p^{3}\right)-\mathrm{C}\left(s p^{3}\right)$ bonds through lactonebased carbene transfer to primary or secondary $\mathrm{C}-\mathrm{H}$ bonds at $\alpha$ amino positions. This enzymatic protocol offers rapid access to an array of chiral $\gamma$-lactone derivatives, which are analogs of sesquiterpene-lactone amino derivatives. The biocatalytic system was rapidly evolved to take $N, N$-dialkylaniline derivatives as substrates, outcompeting $\beta$-hydride elimination to furnish chiral $\beta$-amino lactone products with high catalytic efficiency (up to $4000 \mathrm{TTN}$ ) and in a stereo-divergent manner. A single mutation can control the stereoselectivity of carbene insertion into secondary $\mathrm{C}-\mathrm{H}$ bonds, inverting the two contiguous chiral centers and leading to the opposite enantiomers of the same major diastereomers. Ongoing studies with the family of P411-C10 variants will continue to expand the catalytic potential of $\mathbf{C 1 0}$, a versatile and promiscuous enzyme template for evolution of selective carbene transferases. ${ }^{28}$

\section{AUTHOR INFORMATION}

\section{Corresponding Author}

chenkaikc1990@gmail.com (K.C.)

frances@cheme.caltech.edu (F.H.A.)

\section{ORCID}

Kai Chen: 0000-0002-3325-3536
Frances H. Arnold: 0000-0002-4027-364X

\section{Author Contributions}

K.C. conceived the project. A.Z.Z. and K.C. performed all the experiments and analysis under the guidance of F.H.A. The manuscript was drafted by K.C. and edited by A.Z.Z. and F.H.A.

\section{Funding Sources}

This work was supported by NSF Division of Molecular and Cellular Biosciences grant MCB-1513007, US Army Research Office Institute for Collaborative Biotechnologies cooperative agreement W911NF-19-2-0026, and US Army Research Office Institute for Collaborative Biotechnologies contract W911NF-19D-0001. K.C. thanks the Resnick Sustainability Institute at Caltech for fellowship support.

\section{Notes}

The authors declare no competing financial interests.

\section{ASSOCIATED CONTENT}

Supporting Information. Experimental details, and spectral data for all new compounds. This material is available free of charge via the Internet at http://pubs.acs.org.

\section{ACKNOWLEDGMENT}

We thank Dr. S.-Q. Zhang for computational assistance and mechanistic insights. We are also thankful to Prof. D. Hilvert, Dr. R. K. Zhang, Dr. Noah P. Dunham, Dr. S. Brinkmann-Chen, D. J. Wackelin, Prof. X.-Y. Huang, J. Zhang, and Dr. Y. Yang for helpful discussions and comments.

\section{REFERENCES}

(1) a) Saint-Denis, T. G.; Zhu, R.-Y.; Chen, G.; Wu, Q.-F.; Yu, J.Q. Enantioselective $\mathrm{C}\left(s p^{3}\right)-\mathrm{H}$ Bond Activation by Chiral Transition Metal Catalysts. Science 2018, 359, eaao4798. b) Hartwig, J. F.; Larsen, M. A. Undirected, Homogeneous C-H Bond Functionalization: Challenges and Opportunities. ACS Cent. Sci. 2016, 2, 281-292. c) Wu, W.-T.; Yang, Z.-P.; You, S.-L. in Asymmetric Functionalization of C$H$ Bonds (ed. You, S.-L.) Chapter 1 (Royal Society of Chemistry, Cambridge, 2015), p. 1-66. d) Yamaguchi, J.; Yamaguchi, A. D.; Itami, K. C-H Bond Functionalization: Emerging Synthetic Tools for Natural Products and Pharmaceuticals. Angew. Chem., Int. Ed. 2012, 51, 8960- 9009. e) Zhang, R. K.; Huang, X.; Arnold, F. H. Selective $\mathrm{C}-\mathrm{H}$ Bond Functionalization with Engineered Heme Proteins: New Tools to Generate Complexity. Curr. Opin. Chem. Biol. 2019, 49, 67-75.

(2) a) Doyle, M. P.; Duffy, R.; Ratnikov, M.; Zhou, L. Catalytic Carbene Insertion into C-H Bonds. Chem. Rev. 2009, 110, 704-724. b) Davies, H. M. L.; Beckwith, R. E. J. Catalytic Enantioselective C$\mathrm{H}$ Activation by Means of Metal-Carbenoid-Induced C-H Insertion. Chem. Rev. 2003, 103, 8, 2861-2904. c) Davies, H. M. L.; Manning, J. R. Catalytic C-H Functionalization by Metal Carbenoid and Nitrenoid Insertion. Nature 2008, 451, 417-424.

(3) a) Taber, D. F.; Petty, E. H.; Raman, K. Enantioselective Ring Construction: Synthesis of (+)- $\alpha$-Cuparenone. J. Am. Chem. Soc. 1985, 107, 196-199. b) Doyle, M. P.; Oeveren, A. V.; Westrum, L. J.; Protopopova, M. N.; Clayton Jr, T. W. Asymmetric Synthesis of Lactones with High Enantioselectivity by Intramolecular CarbonHydrogen Insertion Reactions of Alkyl Diazoacetates Catalyzed by Chiral Rhodium(II) Carboxamides. J. Am. Chem. Soc. 1991, 113, 8982-8984. c) Doyle, M. P.; Kalinin, A. V.; Ene, D. G. Chiral Catalyst Controlled Diastereoselection and Regioselection in Intramolecular Carbon-Hydrogen Insertion Reactions of Diazoacetates. J. Am. Chem. Soc. 1996, 118, 8837-8846. d) Davies, H. M. L.; Hansen, T. Asymmetric Intermolecular Carbenoid $\mathrm{C}-\mathrm{H}$ Insertions Catalyzed by Rhodium(II) (S)-N-(p-Dodecylphenyl)sulfonylprolinate. J. Am. Chem. Soc. 1997, 119, 9075-9076. e) Davies, H. M. L.; Hansen, T.; Churchill, 
M. R. Catalytic Asymmetric C-H Activation of Alkanes and Tetrahydrofuran. J. Am. Chem. Soc. 2000, 122, 3063-3070.

(4) a) Suematsu, H.; Katsuki, T. Iridium(III)-Catalyzed Diastereoand Enantioselective C-H Bond Functionalization. J. Am. Chem. Soc. 2009, 131, 14218-14219. b) Weldy, N. M.; Schafer, A. G.; Owens, C. P.; Herting, C. J.; Varela-Alvarez, A.; Chen, S.; Niemeyer, Z.; Musaev, D. G.; Sigman, M. S.; Davies, H. M. L.; Blakey, S. B. Iridium(III)-Bis(imidazolinyl)phenyl Catalysts for Enantioselective $\mathrm{C}-\mathrm{H}$ Functionalization with Ethyl Diazoacetate. Chem. Sci. 2016, 7, 3142-3146. c) Wang, J.-C.; Xu, Z.-J.; Guo, Z.; Deng, Q.H.; Zhou, C.-Y.; Wan, X.-L.; Che, C.-M. Highly Enantioselective Intermolecular Carbene Insertion to $\mathrm{C}-\mathrm{H}$ and $\mathrm{Si}-\mathrm{H}$ Bonds Catalyzed by a Chiral Iridium(III) Complex of a $D_{4}$-Symmetric Halterman Porphyrin Ligand. Chem. Commun. 2012, 48, 4299-4301. d) Wang, H.-X.; Richard, Y.; Wan, Q.; Zhou, C.-Y.; Che, C.-M. Iridium(III)Catalyzed Intermolecular $\mathrm{C}\left(s p^{3}\right)-\mathrm{H}$ Insertion Reaction of Quinoid Carbene: A Radical Mechanism. Angew. Chem., Int. Ed. 2020, 59, 1845-1850. e) Key, H. M.; Dydio, P.; Clark, D. S.; Hartwig, J. F. Abiological Catalysis by Artificial Haem Proteins Containing Noble Metals in Place of Iron. Nature 2016, 534, 534-537.

(5) a) Wang, Y.; Wen, X.; Cui, X.; Zhang, X. P. Enantioselective Radical Cyclization for Construction of 5-Membered Ring Structures by Metalloradical C-H Alkylation. J. Am. Chem. Soc. 2018, 140, 47924796; b) Cui, X.; Xu, X.; Jin, L.-M.; Wojtas, L.; Zhang, X. P. Stereoselective Radical C-H Alkylation with Acceptor/AcceptorSubstituted Diazo Reagents via Co(II)-Based Metalloradical Catalysis. Chem. Sci. 2015, 6, 1219-1224.

(6) a) Díaz-Requejo, M. M.; Belderraín, T. R.; Nicasio, M. C.; Trofimenko, S.; Pérez, P. J. Intermolecular Copper-Catalyzed Carbon-Hydrogen Bond Activation via Carbene Insertion. J. Am. Chem. Soc. 2002, 124, 896-897. b) Fraile, J. M.; Garcia, J. I.; Mayoral, J. A.; Roldan, M. Simple and Efficient Heterogeneous Copper Catalysts for Enantioselective C-H Carbene Insertion. Org. Lett. 2007, 9, 731-733. c) Flynn, C. J.; Elcoate, C. J.; Lawrence, S. E.; Maguire, A. R. Highly Enantioselective Intramolecular Copper-Catalyzed C-H Insertion Reactions of $\alpha$-Diazosulfones. J. Am. Chem. Soc. 2010, 132, 1184-1185. d) Clarke, L. A.; Ring, A.; Ford, A.; Sinha, A. S.; Lawrence, S. E.; Maguire, A. R. Org. Biomol. Chem. Enantioselective Copper Catalysed C-H Insertion Reaction of 2-Sulfonyl-2Diazoacetamides to Form $\gamma$-Lactams. 2014, 12, 7612-7628.

(7) a) Griffin, J. R.; Wendell, C. I.; Garwin, J. A.; White, M. C. Catalytic $\mathrm{C}\left(s p^{3}\right)-\mathrm{H}$ Alkylation via an Iron Carbene Intermediate. $J$. Am. Chem. Soc. 2017, 139, 13624-13627. b) Mbuvi, H. M.; Woo, L. K. Catalytic C-H Insertions Using Iron(III)-Porphyrin Complexes. Organometallics 2008, 27, 637-645. c) Caballero, A.; DespagnetAyoub, E.; Díaz-Requejo, M. M.; Díaz-Rodríguez, A.; GonzálezNúñez, M. E.; Mello, R.; Muñoz, B. K.; Ojo, W.-S.; Asensio, G.; Etienne, M.; Pérez, P. J. Silver-Catalyzed C-C Bond Formation between Methane and Ethyl Diazoacetate in Supercritical $\mathrm{CO}_{2}$. Science 2011, 332, 835-838. d) Rivilla, I.; Gómez-Emeterio, B. P.; Fructos, M. R.; Díaz-Requejo M. M.; Pérez, P. J. Exclusive Aromatic vs Aliphatic $\mathrm{C}-\mathrm{H}$ Bond Functionalization by Carbene Insertion with Gold-Based Catalysts. Organometallics 2011, 30, 2855-2860. e) Gutiérrez-Bonet, Á.; Juliá-Hernández, F.; de Luis, B.; Martin, R. Pd-Catalyzed C( $\left.s p^{3}\right)$ $\mathrm{H}$ Functionalization/Carbenoid Insertion: All-Carbon Quaternary Centers via Multiple $\mathrm{C}-\mathrm{C}$ Bond Formation. J. Am. Chem. Soc. 2016, 138, 6384-6387. f) Reddy, A. R.; Zhou, C.-Y.; Guo, Z.; Wei, J.; Che, C.-M. Ruthenium-Porphyrin-Catalyzed Diastereoselective Intramolecular Alkyl Carbene Insertion into $\mathrm{C}-\mathrm{H}$ Bonds of Alkyl Diazomethanes Generated in situ from $N$ Tosylhydrazones. Angew. Chem., Int. Ed. 2014, 53, 14175-14180. g) Lo, V. K.-Y.; Guo, Z.; Choi, M. K.-W.; Yu, W.-Y.; Huang, J.-S.; Che, C.-M. Highly Selective Intramolecular Carbene Insertion into Primary $\mathrm{C}-\mathrm{H}$ Bond of $\alpha$-Diazoacetamides Mediated by a $(p-$ Cymene)ruthenium(II) Carboxylate Complex. J. Am. Chem. Soc. 2012, 134, 7588-7591. h) Nakagawa, Y.; Chanthamath, S.; Liang, Y.; Shibatomi, K.; Iwasa, S. Regio- and Enantioselective Intramolecular Amide Carbene Insertion into Primary $\mathrm{C}-\mathrm{H}$ Bonds Using $\mathrm{Ru}(\mathrm{II})$-Pheox Catalyst. J. Org. Chem. 2019, 84, 2607-2618.

(8) a) Davies, H. M. L.; Morton, D. Guiding Principles for SiteSelective and Stereoselective Intermolecular C-H Functionalization by
Donor/Acceptor Rhodium Carbenes. Chem. Soc. Rev. 2011, 40, $1857-$ 1869. b) Davies, H. M. L.; Denton, J. R. Application of Donor/Acceptor-Carbenoids to the Synthesis of Natural Products. Chem. Soc. Rev. 2009, 38, 3061-3071.

(9) a) Liao, K. B.; Negretti, S.; Musaev, D. G.; Bacsa, J.; Davies, H. M. L. Site-Selective and Stereoselective Functionalization of Unactivated C-H Bonds. Nature 2016, 533, 230-234. b) Liao, K. B.; Pickel, T. C.; Boyarskikh, V. B.; Bacsa, J. B.; Musaev, D. G. M.; Davies, H. M. L. Site-Selective and Stereoselective Functionalization of Non-Activated Tertiary C-H Bonds. Nature 2017, 551, 609-613. c) Liao, K. B.; Yang, Y. F.; Li, Y. Z.; Sanders, J. N.; Houk, K. N.; Musaev, D. G.; Davies, H. M. L. Design of Catalysts for Site-Selective and Enantioselective Functionalization of NonActivated Primary C-H Bonds. Nat. Chem. 2018, 10, 1048-1055. d) Fu, J. T.; Ren, Z.; Bacsa, J.; Musaev, D. G.; Davies, H. M. L. Desymmetrization of Cyclohexanes by Site- and Stereoselective CH Functionalization. Nature 2018, 564, 395-399. e) Liao, K. B.; Davies, H. M. L. Dirhodium Tetracarboxylates as Catalysts for Selective Intermolecular $\mathrm{C}-\mathrm{H}$ Functionalization. Nat. Rev. Chem. 2019, 3, 347-360.

(10) DeAngelis, A.; Panish, R.; Fox, J. M. Rh-Catalyzed Intermolecular Reactions of $\alpha$-Alkyl- $\alpha$-Diazo Carbonyl Compounds with Selectivity over $\beta$-Hydride Migration. Acc. Chem. Res. 2016, 49, $115-127$.

(11) Zhang, R. K.; Chen, K.; Huang, X.; Wohlschlager, L.; Renata, H.; Arnold, F. H. Enzymatic Assembly of Carbon-Carbon Bonds via Iron-Catalysed $s p^{3} \mathrm{C}-\mathrm{H}$ Functionalization. Nature 2019, 565, 67-72.

(12) Zhang, J.; Huang, X.; Zhang, R. K.; Arnold, F. H. Enantiodivergent $\alpha$-Amino $\mathrm{C}-\mathrm{H}$ Fluoroalkylation Catalyzed by Engineered Cytochrome P450s. J. Am. Chem. Soc. 2019, 141, 97989802.

(13) Selected examples of non-native chemistries by engineered P411s: a) Coelho, P. S.; Wang, Z. J.; Ener, M. E.; Baril, S. A.; Kannan, A.; Arnold, F. H.; Brustad, E. M. A Serine-Substituted P450 Catalyzes Highly Efficient Carbene Transfer to Olefins in vivo. Nat. Chem. Bio. 2013, 9, 485-487. b) Brandenberg, O. F.; Prier, C. K.; Chen, K.; Knight, A. M.; Wu, Z.; Arnold, F. H. Stereoselective Enzymatic Synthesis of Heteroatom-Substituted Cyclopropanes. ACS Catal. 2018, 8, 2629-2634. c) Brandenberg, O. F.; Chen, K.; Arnold, F. H. Directed Evolution of a Cytochrome P450 Carbene Transferase for Selective Functionalization of Cyclic Compounds. J. Am. Chem. Soc. 2019, 141, 8989-8995. d) Hyster, T. K.; Farwell, C. C.; Buller, A. R.; McIntosh, J. A.; Arnold, F. H. Enzyme-Controlled Nitrogen-Atom Transfer Enables Regiodivergent C-H Amination. J. Am. Chem. Soc. 2014, 136, 15505-15508. e) McIntosh, J. A.; Coelho, P. S.; Farwell, C. C.; Wang, Z. J.; Lewis, J. C.; Brown, T. R.; Arnold, F. H. Enantioselective Intramolecular $\mathrm{C}-\mathrm{H}$ Amination Catalyzed by Engineered Cytochrome P450 Enzymes in vitro and in vivo. Angew. Chem., Int. Ed. 2013, 52, 9309-9312. f) Prier, C. K.; Zhang, R. K.; Buller, A. R.; BrinkmannChen, S.; Arnold, F. H. Enantioselective, Intermolecular Benzylic C$\mathrm{H}$ Amination Catalysed by an Engineered Iron-Haem Enzyme. Nat. Chem. 2017, 9, 629-634. g) Farwell, C. C.; Zhang, R. K.; McIntosh, J. A.; Hyster, T. K.; Arnold, F. H. Enantioselective Enzyme-Catalyzed Aziridination Enabled by Active-Site Evolution of a Cytochrome P450. ACS Cent. Sci. 2015, 1, 89-93.

(14) a) DeAngelis, A.; Dmitrenko, O.; Fox, J. M. Rh-Catalyzed Intermolecular Reactions of Cyclic $\alpha$-Diazocarbonyl Compounds with Selectivity over Tertiary C-H Bond Migration. J. Am. Chem. Soc. 2012, 134, 11035-11043. b) Sattely, E. S.; Meek, S. J.; Malcolmson, S. J.; Schrock, R. R.; Hoveyda, A. H. Design and Stereoselective Preparation of a New Class of Chiral Olefin Metathesis Catalysts and Application to Enantioselective Synthesis of Quebrachamine: Catalyst Development Inspired by Natural Product Synthesis. J. Am. Chem. Soc. 2009, 131, 943-953. c) Solovyov, I.; Dar'in, D.; Krasavin, M. Convenient Approach to 2-Substituted (Thio)morpholin-3-ones from $\alpha$-Diazoacetates via $\mathrm{X}-\mathrm{H}$ Carbene Insertion - Lactamization Sequence. Eur. J. Org. Chem. 2019, 45, 7432-7438.

(15) Other cyclic carbenes such as quinoid carbenes have been used for $\mathrm{C}-\mathrm{H}$ insertion: see ref $4 \mathrm{~d}$.

(16) Chen, K.; Zhang, S.-Q.; Brandenberg, O. F.; Hong, X.; Arnold, F. H. Alternate Heme Ligation Steers Activity and Selectivity in 
Engineered Cytochrome P450-Catalyzed Carbene Transfer Reactions. J. Am. Chem. Soc. 2018, 140, 16402-16407.

(17) Chen, K; Huang, X.; Zhang, S.-Q.; Zhou, A. Z.; Kan, S. B. J.; Hong, X.; Arnold, F. H. Engineered Cytochrome $c$-Catalyzed LactoneCarbene B-H Insertion. Synlett 2019, 30, 378-382.

(18) The exact reaction was preliminarily disclosed and studied in ref 11 .

(19) Woods, J. R.; Mo, H.; Bieberich, A. A.; Alavanja, T.; Colby, D. A. Amino-Derivatives of the Sesquiterpene Lactone Class of Natural Products as Prodrugs. Med. Chem. Comm. 2013, 4, $27-33$.

(20) Chen, K.; Arnold, F. H. Engineering Cytochrome P450s for Enantioselective Cyclopropenation of Internal Alkynes. J. Am. Chem. Soc. 2020, 142, 6891-6895.

(21) a) Butler, C. F.; Peet, C.; Mason, A. E.; Voice, M. W.; Leys, D.; Munro, A. W. Key Mutations Alter the Cytochrome P450 BM3 Conformational Landscape and Remove Inherent Substrate Bias. $J$. Biol. Chem. 2013, 288, 25387-25399. b) Cirino, P. C.; Arnold, F. H. Regioselectivity and Activity of Sytochrome P450 BM-3 and Mutant F87A in Reactions Driven by Hydrogen Peroxide. Adv. Synth. Catal. 2002, 344, 932-937. c) Joyce, M. G.; Girvan, H. M.; Munro, A. W.; Leys, D. A Single Mutation in Cytochrome P450 BM3 Induces the Conformational Rearrangement Seen upon Substrate Binding in the Wild-Type Enzyme. J. Biol. Chem. 2004, 279, 23287-23293. d) Coelho, P. S.; Brustad, E. M.; Kannan, A.; Arnold, F. H. Olefin Cyclopropanation via Carbene Transfer Catalyzed by Engineered Cytochrome P450 enzymes. Science 2013, 339, 307-310.

(22) Examples of active-site mutations leading to different stereoselectivity in hemeprotein-catalyzed non-natural reactions: a) Chen, K.; Huang, X.; Kan, S. B. J.; Zhang, R. K.; Arnold, F. H. Enzymatic Construction of Highly Strained Carbocycles. Science 2018, 360, 71-75. b) Yang, Y.; Cho, I.; Qi, X.; Liu, P.; Arnold, F. H. An Enzymatic Platform for the Asymmetric Amination of Primary, Secondary and Tertiary $\mathrm{C}\left(s p^{3}\right)-\mathrm{H}$ Bonds. Nat. Chem. 2019, 11, 987993. c) ref 13b. d) Kan, S. B. J.; Huang, X.; Gumulya, Y.; Chen, K.; Arnold, F. H. Genetically Programmed Chiral Organoborane Synthesis. Nature 2017, 552, 132-136. e) Knight, A. M.; Kan, S. B. J.; Lewis, R. D.; Brandenberg, O. F.; Chen, K.; Arnold, F. H. Diverse Engineered
Heme Proteins Enable Stereodivergent Cyclopropanation of Unactivated Alkenes. ACS Cent. Sci. 2018, 4, 372-377. f) ref 12.

(23) Bach, R. D.; Dmitrenko, O. Strain Energy of Small Ring Hydrocarbons. Influence of $\mathrm{C}-\mathrm{H}$ Bond Dissociation Energies. $\mathrm{J}$. Am. Chem. Soc. 2004, 126, 4444-4452.

(24) Radical pathway has been disclosed for carbene $\mathrm{C}-\mathrm{H}$ insertion reactions catalyzed by cobalt/iridium-porphyrin and ironphthalocyanine complexes: see refs $4 \mathrm{~d}, 5$ and $7 \mathrm{a}$.

(25) Concerted $\mathrm{C}-\mathrm{H}$ insertion is generally considered to take place with rhodium catalysts: a) Doyle, M. P.; Westrum, L. J.; Wolthuis, W. N. E.; See, M. M.; Boone, W. P.; Bagheri, V.; Pearson, M. M. Electronic and Steric Control in Carbon-Hydrogen Insertion Reactions of Diazoacetoacetates Catalyzed by Dirhodium(II) Carboxylates and Carboxamides. J. Am. Chem. Soc. 1993, 115, 958-964. b) ref 8.

(26) Concerted mechanism was also suggested for iron-carbene $\mathrm{C}-$ H insertion reactions: a) Ishii, S.; Zhao, S.; Helquist, P. Stereochemical Probes of Intramolecular C-H Insertion Reactions of Iron-Carbene Complexes. J. Am. Chem. Soc. 2000, 122, 5897-5898. b) HernánGómez, A.; Rodríguez, M.; Parella, T.; Costas, M. Electrophilic Iron Catalyst Paired with a Lithium Cation Enables Selective Functionalization of Non-Activated Aliphatic $\mathrm{C}-\mathrm{H}$ Bonds via Metallocarbene Intermediates. Angew. Chem., Int. Ed. 2019, 58, 13904-13911.

(27) Our previous computational study on the mechanism of lactonecarbene S-H insertion revealed a radical pathway involving hydrogen atom abstraction followed by stereo-invertive radical rebound at the $\alpha$ chiral center, see ref 16.

(28) Reviews on exploring new enzymatic activities: a) Prier, C. K.; Arnold, F. H. Chemomimetic Biocatalysis: Exploiting the Synthetic Potential of Cofactor-Dependent Enzymes to Create New Catalysts. $J$. Am. Chem. Soc. 2015, 137, 13992-14006. b) Chen, K.; Arnold, F. H. Engineering New Catalytic Activities in Enzymes. Nat. Catal. 2020, 3, 103-113. c) Leveson-Gower, R. B.; Mayer, C.; Roelfes, G. The Importance of Catalytic Promiscuity for Enzyme Design and Evolution. Nat. Rev. Chem. 2019, 3, 687-705. d) Renata, H.; Wang, Z. J.; Arnold, F. H. Expanding the Enzyme Universe: Accessing NonNatural Reactions by Mechanism-Guided Directed Evolution. Angew. Chem., Int. Ed. 2015, 54, 3351-3367. 


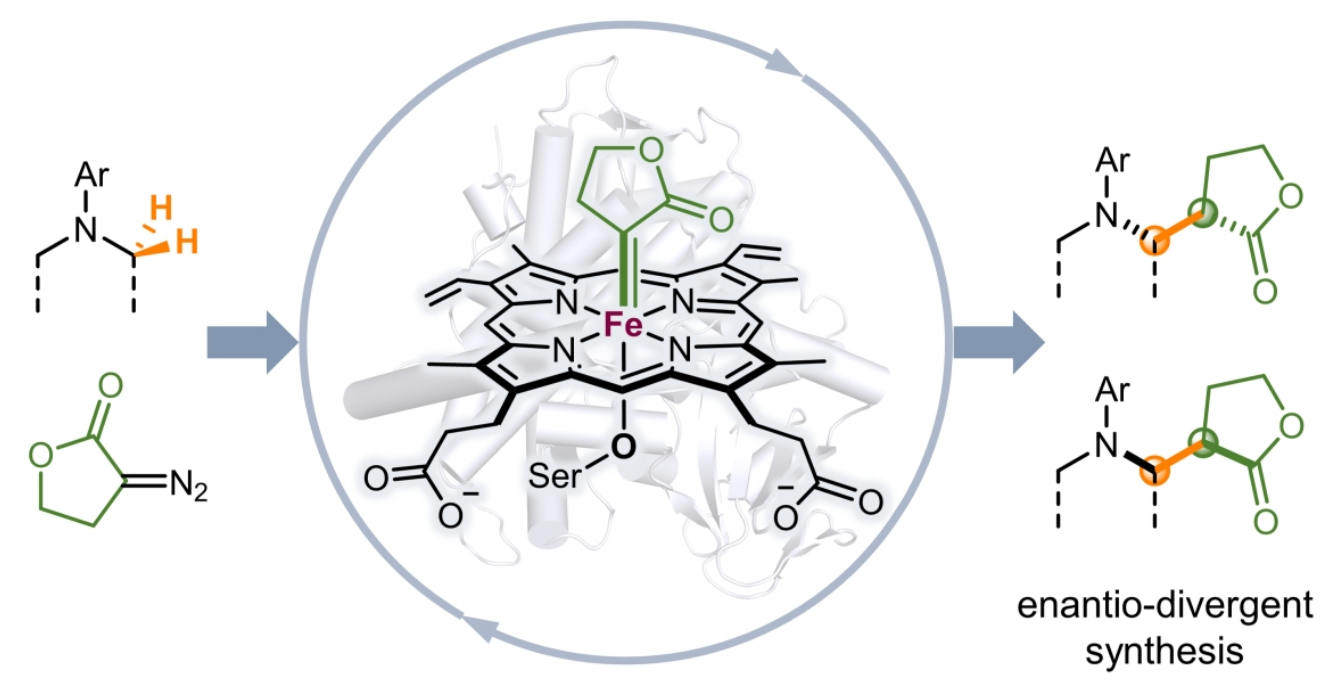

TTN up to 4000 , d.r. up to $99: 1$, ee up to $99 \%$

Graphic abstract

$475 \times 266 \mathrm{~mm}(150 \times 150 \mathrm{DPI})$ 